\title{
Purification and Some Properties of Pectinesterase from Potato (Solanum tuberosum L.) Alpha Cultivar
}

\author{
Julio Montañez Sáenz ${ }^{1}$, Alejandro Téllez ${ }^{2,3}$, Heliodoro de la Garza ${ }^{1}$, María de la Luz \\ Reyes $^{1}$, Juan Carlos Contreras-Esquivel ${ }^{1,4}$ and Cristóbal Noé Aguilar ${ }^{1,3^{*}}$ \\ ${ }^{1}$ Food Research Dept. Faculty of Chemical Sciences. Universidad Autónoma de Coahuila, Saltillo, Coah P.O.Box \\ 252, 25000 Mexico. ${ }^{2}$ Centro de Investigaciones Biologicas del CSIC, Spain. ${ }^{3}$ Biotechnology Dept. CBS. Universidad \\ Autónoma Metropolitana, Iztapalapa, Mexico. ${ }^{4}$ CINDEFI, Faculty of Exact Sciences, Universidad Nacional de La \\ Plata, La Plata, Argentina
}

\begin{abstract}
Pectinesterase was extracted from potato alpha cultivar, purified and partially characterized The used protocol resulted in a 58.8-fold purification (51 850.2 units $/ \mathrm{mg}$ protein) with $15.5 \%$ recovery of pectinesterase activity. The purified enzyme had a molecular weight of $27 \mathrm{kDa}$ and its isoelectric point was around 4.5 with $\mathrm{pH}$ and temperature optima of 8.0 and $60^{\circ} \mathrm{C}$, respectively. The purified enzyme had a single symmetric peak of specific activity after chromatographic steps. The homogeneity of the purified pectinesterase was confirmed by gel filtration and polyacrylamide electrophoresis gel.
\end{abstract}

Key words: Extraction, purification, properties, pectinesterase, potato

\section{INTRODUCTION}

Pectinestarase (PE, pectin methylesterase, pectin pectylhydrolase, EC, 3.1.1.11) removes methoxyl groups from methylated galacturonic residues of pectic substances (Sáez et al., 1983). This enzyme is widely distributed in higher plants and can be found in different plant tissues; mainly those contained in fruits (Baron \& Thibault, 1985).

PE has been purified and characterized from several fruit sources, including tomato (Lee \& Macmillan, 1968), orange (Versteeg et al., 1978), papaya (Lourenco \& Catutani, 1984; Fayyaz et al., 1994), apple (Castaldo et al., 1989), kiwi (Giovane et al., 1990), grapefruit pulp (Seymour et al., 1990) and mandarin orange fruit (Rillo et al., 1992). From other plant sources, PE has been extracted and partially purified from potato (Puri et al., 1982) and from seeds of Ficus awkeotsang (Komae \& Misaki, 1989; Komae et al.,1990).

Some reports established that plants contain multiple forms of PE (Hultin \& Levine, 1963; Evans \& McHale, 1978) differing in molecular weight, charge and glycosylation degree which affects the affinity for pectin and the thermostability of the PE forms (Giovane et al., 1990).

Control of PE activity in situ is very important in the food industry because of its influence on the final product quality; particularly to produce low methoxyl pectins in citrus peels (Taylor, 1982) to obtain cloudy citrus juice (Nath \& Ranganna, 1977) and high viscosity tomato juice and puree (Nath et al., 1983) to improve texture and firmness in some processed fruits and vegetables (Pilnik \& Voragen, 1991; Stanley et al., 1995) and color, limpness and other physicochemical parameters of fried potatoes (Chávez et al., 1998; AguileraCarbó et al., 1999). In the last case, the control of $\mathrm{PE}$ activity is a critic factor due the potato tubers of low and medium specific gravity (Alpha cultivar, 1.065-1.085) can be used to obtain fried products in México (Aguilar, 1995; Aguilar et al., 1997). For this reason, the extraction, quantification, purification and characterization is needed if one wishes to measure the effect of temperature on activation/inactivation processes during the Low Temperature-Long Time (LT-LT) blanching and to design the better blanching conditions (Aguilera-Carbó et al., 1996a). 
Recently, we published the procedures to develop and optimize an enzyme extraction, which were used for further studies on in situ PE activation which improved the quality of fried potato products (Aguilera-Carbó et al., 1996b and 1999; Contreras-Esquivel et al., 1999). A report was published on partial purification of $\mathrm{PE}$ from potato (Puri et al., 1982). It was considered important to develop a protoccol of total purification for the PE from potato, which could give a complete information of such enzyme. In the present paper, we describe the PE purification presenting some characteristics of this enzyme extracted from potato tubers (Solanum tuberosum L.) alpha cultivar, which could be of interest for optimize the LT-LT blanching of potato strips and chips and improves the quality of these products.

\section{MATERIAL AND METHODS}

Potato tubers (Solanum tuberosum L) alpha cultivar were purchased in a local market of Saltillo, Coahuila, México with a specific gravity of 1.087. Citrus pectin (P-9125) with an esterification degree of $68 \%$, sodium chloride used for enzyme extraction and some other analytical grade chemicals were obtained from Sigma. BIO$\mathrm{RAD}^{\circledR}$ products supplied all chemicals needed for purification.

Enzyme extraction. PE from potato tubers were extracted according to the methods developed by Aguilera-Carbó et al., (1996b) and ContrerasEsquivel et al., (1999).

Determination of PE activity. PE activity was assayed by the titration method proposed by Kertesz (1955). This method involves the measurement of the releasing rate of carboxyl groups in a pectin solution $(1 \% \mathrm{w} / \mathrm{v})$, at $30^{\circ} \mathrm{C}$ and $\mathrm{pH}$ of 7.0. The substrate was prepared and stored according to the procedure described by Rouse \& Atkins (1955). The initial rate or reaction was obtained when the free carboxyl groups were titred with $20 \mathrm{mM} \mathrm{NaOH}$, considering that the equivalent amount of $\mathrm{NaOH}$ solution used is proportional to the PE activity. One PE activity was defined as the amount of the enzyme able to release $1 \square \mathrm{mol}$ of carboxyl groups per minute under the above mentioned reaction conditions.
Protein Assay. The protein concentration was determined according to the microassay of Bradford (BIO-RAD ${ }^{\circledR}$ ) using a calibration curve made with bovine serum albumin.

Pretreatment of the PE extract crude. PE crude extract obtained from potato suspension was dialyzed in cellulose membrane against a phosphate buffer ( $\mathrm{pH}$ 7.0) during overnight for 12 $\mathrm{h}$ at $4^{\circ} \mathrm{C}$. Then the enzyme was microfiltrated using Nalgene filter of nylon membrane of 0.2 $\mathrm{mM}$.

Pre-purification of PE. Dialyzed and microfiltrated PE extract was used to carry out a chromatography as preliminary fractionation on a precolumn EconoPac ${ }^{\circledR}\left(\right.$ Bio-Rad $\left.^{\circledR}\right)$ conected to BioLogic LP System ${ }^{\circledR}\left(\right.$ Bio-Rad $\left.^{\circledR}\right)$.

Anion exchange chromatography. Two fractions obtained as active fractions in the preliminary chromatography were used to performed an anion exchange chromatography using a column Mono $\mathrm{Q}\left(\mathrm{Bio}^{-\mathrm{Rad}^{\circledR}}{ }^{\circledR}\right)$ in the same BioLogic LP System. The concentrated samples were applied to a column of anion exchange, equilibrated with 0.02 $\mathrm{M}$ sodium phosphate buffer $(\mathrm{pH}$ 7.5) containing $0.3 \mathrm{M} \mathrm{NaCl}$ and $0.02 \%$ sodium azide.

Gel filtration chromatography. The molecular weight of the native PE was determined by gel filtration chromatography using a FPLC system $\left(\right.$ Bio- $\left.^{-R^{\circledR}}{ }^{\circledR}\right)$ with a column of Sephadex G-100. The column was equilibrated using the following proteins: ovoalbumin (43 $\mathrm{kDa})$, carbonic anhydrase (30 kDa), chymotripsinogen A (25 $\mathrm{kDa})$, ribonuclease $(14 \mathrm{kDa})$ and aprotinin $(6.5$ $\mathrm{kDa})$. The column was eluted at flow rate of 0.5 $\mathrm{mL} / \mathrm{min}$ with a phosphate buffer $(0.02 \mathrm{M}, \mathrm{pH} 7.5)$ and $300 \mathrm{mM} \mathrm{NaCl}$.

Gel electrophoresis analysis. Gel electrophoresis in denaturing conditions was performed in sodium dodecyl sulfate (SDS-PAGE) according to the method of Laemmli (1970). The gels contained a final acrylamide concentration of $10 \%$. Staining of slab gels was done with Coommassie Brilliant Blue and Silver Nitrate. The molecular weight markers were ovoalbumin (43 kDa) carbonic anhydrase $(30 \mathrm{kDa})$ trypsinogen $(24 \mathrm{kDa})$, lysosyme $(14.3 \mathrm{kDa})$ and aprotinin $(6.5 \mathrm{kDa})$. 
Isoelectric point determination. The evaluation of isoelectric point $(p I)$ was performed on a Phast System apparatus (Pharmacia) in the $\mathrm{pH}$ range 3-9 using a calibration kit containing proteins with $p I$ ranging over 8.7-3.5.

pH optimum and thermal stability of PE. The $\mathrm{pH}$ dependence of potato $\mathrm{PE}$ was evaluated in a $\mathrm{pH}$ range 3.0-9.0 at $25^{\circ} \mathrm{C}$, using the titrimetric method of Kertesz (1955). Each sample of PE (1.0 $\mathrm{mL}$ ) was preheated for $30 \mathrm{~min}$ at each temperature tested and immediately the PE activity was assayed.

\section{RESULTS AND DISCUSSION}

A summary of the steps utilized to purify the PE from potato tissue is given in Table 1. The process of $\mathrm{PE}$ purification was achieved with a protocol consisting of five steps.

The protocol carried out was repeated several times and was found to be highly reproducible. The second step gave a $100 \%$ yield. This value was higher to the values obtained for apple PE (Castaldo et al., 1989) and for Ficus awkeotsang PE (Lin et al., 1989), which were $75 \%$. On the other hand, this value was approximately equal to the values obtained for tomato PE (Korner et al., $1980)$ and mandarin orange PE $(96 \%)$ reported by Rillo et al., (1992).

Preliminary chromatography (third step) gave a $42.12 \%$ yield, but it did not show a good selectivity for PE. By this step, a purification factor of 2.2 was obtained. However, this step was useful to eliminate many proteins presents in the dialyzed extract, giving two active fractions. These results were similar to those reported to PE from mandarin orange fruit by Rillo et al., (1992) who reported a yield of 48.6 during the affinity chromatography.

During the fourth step, the possibility of two enzymatic forms was rejected due to that one active fraction was obtained. In this step, the enzyme was found to be eluted as a single peak. After this step, a $36.11 \%$ yield was reached and the PE was purified 4.3 -folds.

For further purification of the potato PE, a gel filtration chromatography was used. The purified PE gave a $15.55 \%$ yield and 58.8-fold purification. This step was the major feature of the protocol proposed due it showed a good selectivity for PE, in fact, by this step the purification factor was higher.

Table 1. Purification of pectinesterase from potato Alpha cultivar

\begin{tabular}{lccccc}
\hline Purification steps & $\begin{array}{c}\text { PE activity } \\
(\mathrm{U} / \mathrm{mL})\end{array}$ & $\begin{array}{c}\text { Total activity } \\
\text { (Units) }\end{array}$ & $\begin{array}{c}\text { Specific activity } \\
\text { (Units/mg protein) }\end{array}$ & $\begin{array}{c}\text { Purification } \\
\text { (fold) }\end{array}$ & $\begin{array}{c}\text { Yield } \\
(\%)\end{array}$ \\
\hline Crude extract & 16.2 & 810.0 & 881.2 & 100 & - \\
Dialyzed extract & 18.2 & 910.0 & 1121.3 & 100 & - \\
Preliminary chromatography & 112.5 & 341.2 & 1934.3 & 42.12 & 2.2 \\
Anion exchange chromatography & 115.3 & 292.5 & 3826.4 & 36.11 & 4.3 \\
Gel filtration chromatography & 97.4 & 126.4 & 5185.2 & 15.55 & 58.8 \\
\hline
\end{tabular}

The specific activity (5185.2 units/mg protein) of the purified pectinesterase obtained in this procedure was five times higher to the specific activities of tomato PE and kiwi PE (1159.93 and 974 units/mg protein) reported by Lee \& Macmillan (1968) and Giovane et al., (1990) respectively.

The gel obtained from SDS-PAGE from the active fraction corresponding to PE enzyme is presented in Figure 1. One band of protein was observed. SDS-PAGE showed that the enzyme consists of a single polypeptide chain. A molecular weight of $27 \mathrm{kDa}$ was estimated.

According to several reports of the same enzyme purified from other sources, the molecular weight obtained in this work was in the range proposed by Delincee \& Radola (1970). Puri et al., (1982) reported an apparent molecular weight of $25 \mathrm{kDa}$ for potato Russet Burbank Cultivar, while in our case, the PE from potato Alpha cultivar showed a molecular wieght of $27 \mathrm{kDa}$, which demostrated that tissues of potato of different cultivars have PE's with similar molecular characteristics. 
A comparison of molecular weights reported for PEs from several sources is presented in Table 2. Isoelectrofocusing determination showed a $p I$ value of 4.5 , which was different of that reported by Rillo et al., (1992). They observed a $p I$ value higher than 8.65, however this value was uncertainly determined due to the PE focalization at the end of the gel. Our findings were comparable to that reported by Komae et al., (1990) for PE from Ficus awkeotsang. It is important to state that the $p I$ values of PE from fruit sources are different (higher than 8.0) with respect to those obtained from vegetable sources (lower than 6.0) (Versteeg et al., 1978; Rillo et al., 1992).

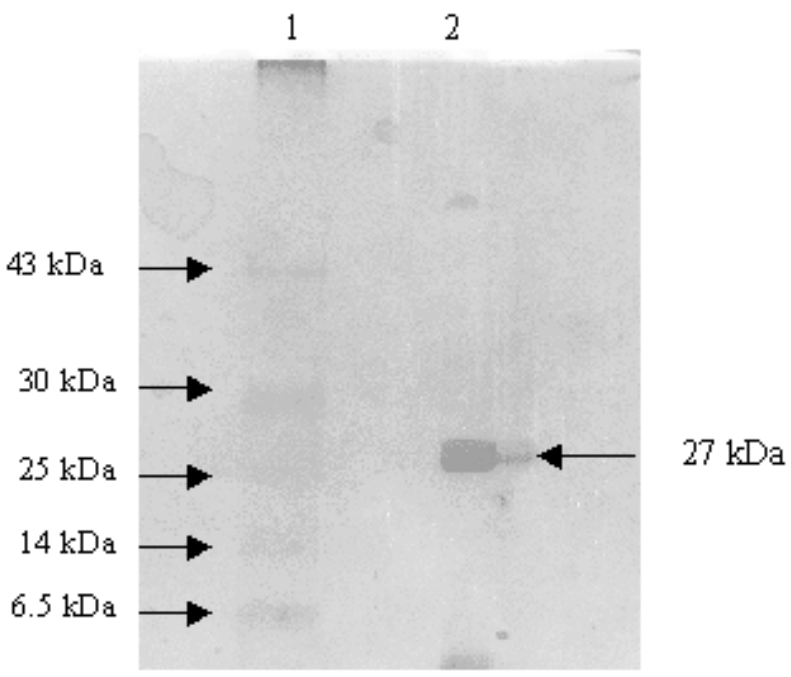

Figure 1. SDS-PAGE of final purification step of PE from potato. Lane 1 are Molecular weight markers (see Materials and Methods) and Lane 2 is potato PE.

Table 2. Molecular weights of pectinesterases from several sources.

\begin{tabular}{lcr}
\hline Source & $\begin{array}{c}\text { Molecular weight } \\
(\mathrm{KDa})\end{array}$ & \multicolumn{1}{c}{ Reference } \\
\hline Tomato & $24.0-28.0$ & Delincee \& Radola (1970) \\
Tomato & $23.7-35.5$ & Pressey \& Avants (1972) \\
Orange & $35.5-37.3$ & Versteeg (1979) \\
Papaya & 53.0 & Lourenco \& Catutani (1984) \\
Var. solo & & Lim \& Chung (1989) \\
Papaya & 21.0 & Rillo et al., (1992 \\
Mandariine & 37.0 & Fayyaz et al., (1994) \\
Orange fruit & & Puri et al., (1982) \\
Papaya & 32.0 & This study \\
Var.exotica & & \\
Potato & 25.0 & \\
Potato & 27.0 & \\
Var. alpha & &
\end{tabular}

The thermal stability of PE (Figure 2) was calculated by incubing the enzyme for $30 \mathrm{~min}$ at increasing temperature. The activity was substantially increased up to $60{ }^{\circ} \mathrm{C}$ and then it decreased to about $30 \%$ at 70 ${ }^{\circ} \mathrm{C}$ and $70 \%$ at $90{ }^{\circ} \mathrm{C}$. The PE from potato alpha cultivar appeared thermostable. The thermal stability of this enzyme was considerably higher than that found for other PEs, which generally was up to $60^{\circ} \mathrm{C}$. These results are not similar to those reported by Puri et al., (1982), who obtained an optimum temperature of $55^{\circ} \mathrm{C}$ and a $\mathrm{Q} 10$ of 1.33 in the temperature range of 15 to $45^{\circ} \mathrm{C}$. It is important to note, that the PE from potato Alpha Cultivar was highly stable in a wide temperature range ( 30 up to $90^{\circ} \mathrm{C}$ ), which could be very attractive for the thermal processing of this cultivar. Last point is very important because, LT-LT blanching process is generally carried out at temperature range between $50-70{ }^{\circ} \mathrm{C}$ with the objective of an in situ activation of native PE. This study demonstrates that the maximum activity of potato $\mathrm{PE}$ is around $60{ }^{\circ} \mathrm{C}$, and this temperature is the optimum for reach better textures in potato tissue by LT-LT blanching.

The effect of $\mathrm{pH}$ on PE activity is shown in Figure 3. The $\mathrm{PE}$ enzyme showed a maximum activity at $\mathrm{pH} 8$ and was underdetectable below $\mathrm{pH}$ 5.0. The $\mathrm{pH}$ optimum found for potato PE was similar to that found for PEs from fruit sources, which generally was in the range 7-9.

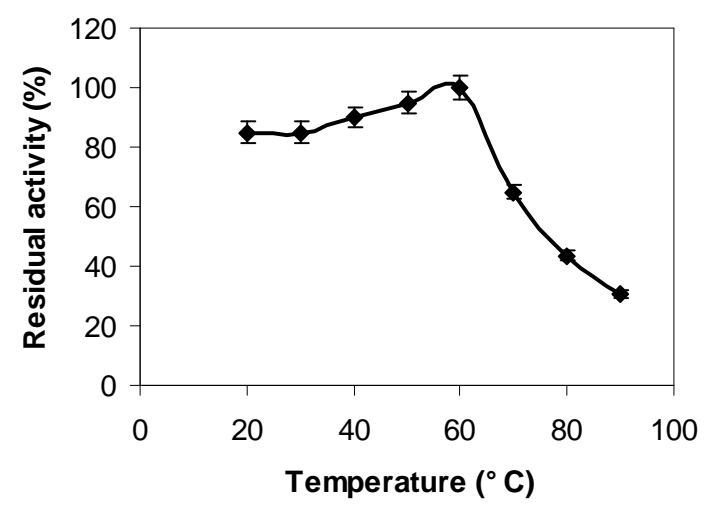

Figure 2. Thermal stability determination of potato PE. 


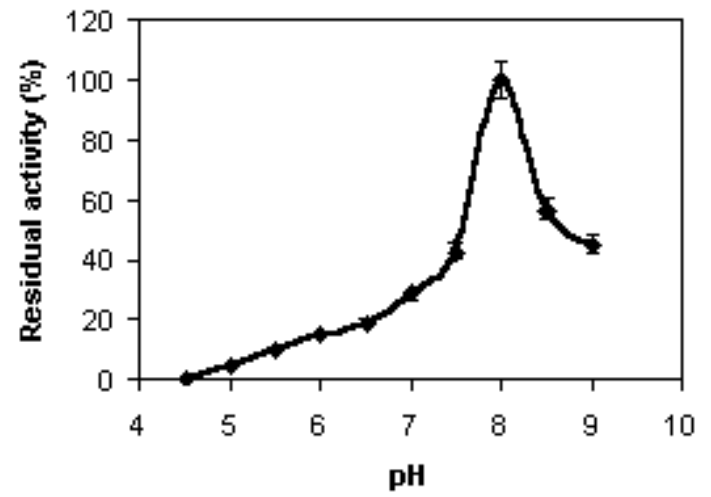

Figure 3. $\mathrm{pH}$ optimum determination of potato PE.

\section{AKNOWLEDGEMENTS}

Authors wish to thank National Council for Science \& Technology (CONACYT, México 83076/124550). This research was partially supported by the CGEPI-UAdeC and forms part of the thesis work of Julio Cesar Montañez. Authors wish to thank researchers of PP-4 of Biotechnology Dept, in the Universidad Autonoma Metropolitana Iztapalapa for facilities and critical opinions offered.

\section{RESUMO}

A pectinesterase foi extraída da batata (cultivar do alfa), purificada e parcialmente caracterizada. $\mathrm{O}$ protocolo usado levou a uma proteína purificada 58,8 vezes (51 850,2 units/mg da proteína) com uma recuperação de $15,5 \%$ da atividade da proteína. A enzima purificada apresentou um peso molecular de $27 \mathrm{kDa}$ e seu ponto isoelétrico foi ao redor 4,5. A pectinesterase exibiu $\mathrm{pH}$ e temperatura ótimos de respectivamente 8,0 e $60^{\circ} \mathrm{C}$. A enzima purificada apresentou um único pico simétrico de atividade específica após as etapas de cromatografia. A homogeneidade da pectinesterase purificada foi confirmada por filtração em gel e por eletroforese em gel de poliacrilamida.

\section{REFERENCES}

Aguilar, C.N. (1995), Application of no ordinary blanching to improves the quality of processed fruits and vegetables. In: Research and technological development in Coahuila, ed. COECYT-Coahuila, Saltillo, México. 11-16
Aguilar, C.N., Anzaldúa-Morales, A., Talamás, R. \& Gastelum, G. (1997), Low Temperature blanch improves textural quality in french fries. J Food Sci. 62: $568-571$.

Aguilera-Carbó, A., Aguilar, C.N., Contreras-Esquivel, J.C., De la Garza, H. \& Vidal, A. (1996a), Effect of in situ activation of pectinesterase on color and texture of french fried potatoes. Iberoam Appl Biotechnol CIIDIR. 1: 7-14

Aguilera-Carbó, A., Montañez, J.C., Correa, C., Contreras-Esquivel, J.C. \& Aguilar, C.N. (1996b), Extraction of pectin methyl esterase from potato tissue (Alpha cultivar). Conference presented at $3^{\text {rd }}$ International Congress of chemical-biological Sciences, 10-12 March, UDLA, México

Aguilera-Carbó, A., Montañez, J.C., Anzaldúa-Morales, A., Reyes, M.L., Contreras-Esquivel, J.C. \& Aguilar, C.N. (1999), Improvement of color and limpness of fried potatoes by in situ pectinesterase activation. Eur Food Res Technol. 210: 49-52

Baron, A. \& Thibault, J.F. (1985), Les enzymes pectolytiques. In: Hydrolases et Dépolimérases, ed. A. Mouranche \& C.Costes. Gauthier-Villars, Paris, pp. 143-164

Castaldo, D., Quagliuolo, L., Servillo, L., Balestrieri, C. \& Giovane, A. (1989), Isolation and characterization of pectinmethylesterase from apple fruit. J Food Sci. 54: 653-655, 673

Chávez, S.N., De la Garza-Toledo, H., Aguilera-Carbó, A., Montañez, J.C., Contreras-Esquivel, J.C. \& Aguilar, C.N. (1998), Effect of no ordinary blanchings on physico-chemical and microbiological quality of fried potato strips. Ind Alim. 20: 19-22

Contreras-Esquivel, J.C., Correa-Robles, C., Aguilar, C.N., Rodríguez, J., Romero, J. \& Hours, R.A. (1999), Pectinesterase extraction from mexican lime (Citrus aurantifolia Swingle) and prickly pear (Opuntia ficus indica L.) peels. Food Chem. 65: 153156

Delincee, H. \& Radola, B.J. (1970), Some size and charge properties of tomato pectin methylesterase. Biochem Biophys Acta. 47: 183-185

Evans, R. \& McHale, D. (1978), Multiple forms of pectinesterase in limes and oranges. Phytochemistry. 17: $1073-1075$

Fayyaz, A., Asbi, B.A., Ghazali, H.M., Che Man, Y.B. \& Jinap, S. (1994), Purification and molecular properties of papaya pectinesterase. Food Chem. 49: 373-378

Giovane, A., Quagliulo, L., Castaldo, D., Servillo, L. \& Balestrieri, C. (1990), Pectin methylesterase from Actinidia chinensis fruits. Phytochemistry. 29: 28212823

Hultin, H. \& Levine, A. (1963), On the occurrence of multiple molecular forms of pectinesterase. Arch Biochem Biophys. 101: 396-402 
Kertesz, Z. (1955), Pectic enzymes. In: Methods in enzymology (Vol. 1), ed.S.P. Colowik \& N.O. Kaplan. Academic press, New York, USA. 158

Komae, K., and Misaki, A. (1989), Isolation and characterization of gel-forming polygalacturonoide from seeds of Ficus awkeotsang. Agric Biol Chem. 53: $1237-1245$

Komae, K., Sone, Y., Kakuta, M. \& Misaki, A. (1990), Purification and characterization of pectinesterase from Ficus awkeotsang. Agric Biol Chem. 54: 14691476

Korner, B., Zimmermann, G. \& Berk, Z. (1980), Orange pectinesterase: purification, properties and effect on cloud stability. J Food Sci. 45: 1203-1206

Laemmli, U. K. (1970), Cleavage of structural proteins during the assembly of the head of bacterophage, T4. Nature. 227: 680

Lee, M. \& Macmillan, J.D. (1968), Mode of action of pectic enzymes. I. Purification and certain properties of tomato pectinesterase. Biochemistry. 7: 4005-4010

Lin, T., Liu, C., Chen, S. \& Wang, W. (1989), Purification and characterization of pectinmehtylesterase from Ficus aweotsang Makino Achenes. Plant Physio. 91: 1445-1453

Lourenco, E. J. \& Catutani, A.T. (1984), Purification and properties of pectinesterase from papaya. $J \mathrm{Sci}$ Food Agric. 35: 1120-1127

Nath, N. \& Ranganna, S. (1977), Time/temperature relationship for thermal inactivation of pectinesterase in mandarin orange (Citrus reticulata Blanco) juice. $J$ Food Technol. 12: 411-419

Nath, N., Rao, A. \& Gupta, R. (1983), Thermal resistance of pectin methyl esterase in juice of pusaruby tomatoes. Ind Food Packer. 37: 30-38

Pilnik, W. \& Voragen, A. (1991), The significance of endogenous and exogenous pectic enzymes in fruit and vegetable processing. In: Food Enzymology, Vol. 1, ed. P.F. Fox. Elsevier Applied Science, London. 304-336
Puri, A., Solomos, T. \& Kramer, A. (1982), Partial purification and characterization of potato pectinesterase. Food Chem. 8: 203-213

Rillo, L., Castaldo, D., Giovane, A., Servillo, L., Balestrieri, C. \& Quagliuolo, L. (1992), Purification and properties ofpectin methylesterase from mandarin orange fruit, J Agric Food Chem. 40: 591-593

Rouse, A. \& Atkins, C. (1955), Pectinesterase and pectin in commercial citrus juices as determined by methods used at the Citrus Experimental Station. Fla Agr Expt Sta Bull. 570

Sáez, S., Villarroel, P., Parraguirre, V. \& Pennachiotti, I. (1983), Determinación de actividad pectinesterásica y extracción de pectina a partir de sub-productos cítricos. Alimentos (Chile). 8: 38-39

Seymour, T., Preston, J., Wicker, L., Lindsay, J.A. \& Marshall, M.R. (1990), Purification and properties of pectinesterase of marsh white grapefruit pulp, J Agric Food Chem. 39: 1080-1085

Stanley, D.W., Bourne, M., Stone, A. \& Wismer, W. (1995), Low temperature blanching effects on chemistry, firmness and structure of canned green beans and carrots. J Food Sci. 60: 327-333

Taylor, A. (1982), Intramolecular distribution of carboxyl groups in low methoxyl pectins-a review. Carbohydr Polym. 2: 9-17

Versteeg, C., Rombouts, F. \& Pilnik, W. (1978), Purification and some characteristics of two pectinesterase insoenzymes from orange. Lebensm Wiss Technol. 11: 267-274

Received: December 16, 1999 Revised: June 12, 2000; Accepted: July 10, 2000. 